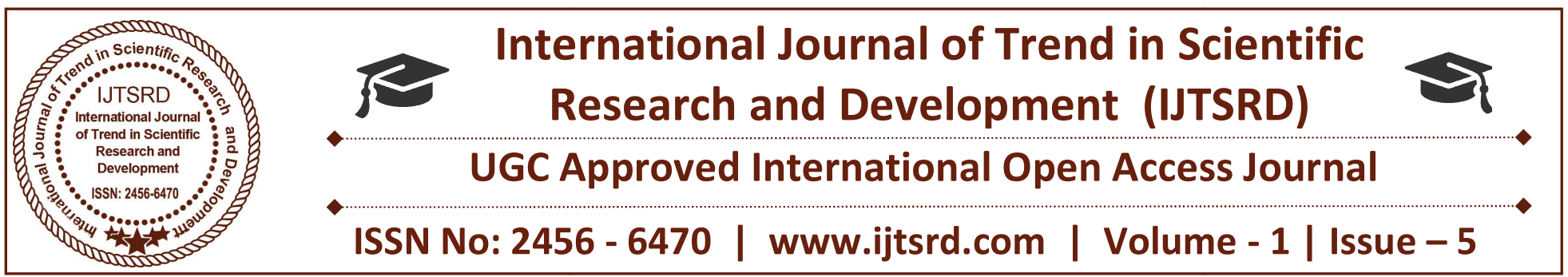

\title{
Study on Nutritious Multigrain Weaning Mix
}

\author{
Dr. Bhavana Chauhan \\ S.M.Patel College Of HomeScience, \\ Vallabh Vidyanagar, Gujarat, India
}

\section{ABSTRACT}

The study was on the development of weaning food based on wheat, chickpea and ragi and adapting the Malting, Germinating and Popping technology. The composition was done for the physico- chemical and nutritional quality of malted, germinated and popped weaning mix with the control weaning mix with similar composition. The results suggest that the weaning foods based on wheat, chickpea and ragi are nutritionally balanced and possess good growth promoting quality. The traditional technologies such as Malting, Germinating and Popping of cereals and legumes could be easily adapted to prepared weaning and supplementary foods from wheat, chickpea and ragi. Malting, Germinating and Popping have a high potential for developing low cost weaning and supplementary foods.

\section{INTRODUCTION}

Having a baby at home is a wonderful experience. Looking after the baby and caring for it is an even more fulfilling experience. There are several important stages in an infant's growth. But one of the most important aspects, and often misunderstood stage, is that of weaning. The introduction to solid feeding and the gradual replacement of milk by solid food as the main source of nutrition is the process known as weaning. Weaning is a period of transition for the infant during which the diet changes in terms of consistency and source (Usha et al., 2010). At six months, a baby's digestive system has matured enough to cope with solid food, and other developmental changes (such as the ability to bite and chew) mean your baby is ready to experience new tastes and textures.

From a liquid milk-based diet, the child is gradually introduced to semi-solid foods. Such semi-solid foods are referred to as complementary foods. A complementary food should ideally be easily digestible, have high energy density and low bulk (Ezeji and Ojimelukwe, 1993). Between the ages of 68 months pureed and mashed foods can be introduced and given from a cup or bowl.

However, the capacity of a weaning diet to meet the protein and energy requirements of infants depends on its nutritional quality as well as its dietary bulk. This can be achieved through legume supplementation of cereal-based weaning foods. However, their role appears to be limited because of several factors including low protein and starch digestibility, poor mineral bioavailability and high anti-nutritional factors (Kamchan et al., 2004, Negi et al., 2001). It has been reported that protein and thiamin (Sattar et al., 1989, Savelkoul 1992) mineral bioavailability and protein and starch digestibility (Preet and Punia, 2000) increased, whereas phytic acid and tannin decreased during germination of legumes.

Legumes are known to contain lysine in a quantity that exceeds the requirements for human but with the low content of sulphur amino acids. Cereals, on the other hand, are high in the sulphur amino acids but deficient in lysine. A mutual complementation of amino acids and consequent improvement in protein quality is therefore achieved when legumes are blended with cereals in the right proportions. Cereals form the major part of most weaning mixes and contribute to $70-80 \%$ of daily energy intake (Mahajan 
and Chattopadhey, 2000). However, they are deficient in one or two essential amino acids. Legumes are largely replacing milk and other sources of animal proteins, which are expensive and not readily available in India as suitable substitutes for high quality protein. Therefore, supplementing with legumes and other nutrient dense food products improves the nutritional quality of cereals by complementing their limited amino acids, lysine and tryptophan (Hulse, 1991).

\section{MATERIALS AND METHODS}

Wheat, chickpea and ragi purchased from a local market (Anand, India) were cleaned and used for the studies. Three different processing techniques (Malting, Germination \& Popping) used for the development of processed multi grain weaning mix.

\section{A) Malting:}

Wheat, chickpea and ragi were soaked separately in water for overnight and then after removal of water they were sun dried, till they become completely dry and flour was prepared using grinding mill.

\section{B) Germination:}

Wheat, Chickpea and Ragi were soaked overnight in water and then packed individually in wet muslin cloth for sprouting. After sprouting they were sundried and then flour was made using the grinding mill.

\section{C) Popping:}

Wheat, Chickpea and Ragi were roasted in dry sand individually at high temperature for short period of time, till they become completely roasted and after that flour was prepared using the grinding mill.

Nestle Cerelac Stage $1(6+$ months $)$ Wheat based product was used as a control product. The experimental product included the addition of different proportion of cereals and pulse combination. The multigrain weaning mix was prepared from the different processed flours (i.e. Malting, Germination and Popping).

\section{Development of Standard Product:}

\begin{tabular}{|c|c|c|c|c|c|}
\hline \multirow{2}{*}{ Ingredients } & \multicolumn{5}{|c|}{ Experimental Weaning Mix } \\
\cline { 2 - 6 } & $\begin{array}{c}\text { Control } \\
(\mathbf{g})\end{array}$ & $\begin{array}{c}\text { A } \\
\text { Without Process (g) }\end{array}$ & $\begin{array}{c}\text { B } \\
\text { Malted } \\
(\mathbf{g})\end{array}$ & $\begin{array}{c}\text { C } \\
\text { Germinated } \\
(\mathbf{g})\end{array}$ & $\begin{array}{c}\text { D } \\
\text { Popped } \\
(\mathbf{g})\end{array}$ \\
\hline Nestle Cerelac & 100 & - & - & - & - \\
\hline Wheat flour & - & 25 & 25 & 25 & 25 \\
\hline Chickpea flour & - & 10 & 10 & 10 & 10 \\
\hline Ragi flour & - & 25 & 25 & 25 & 25 \\
\hline Skimmed Milk Powder & - & 30 & 30 & 30 & 30 \\
\hline Crystal sugar powder & - & 10 & 10 & 10 & 10 \\
\hline
\end{tabular}

For Standardization of experimental product the instant weaning mix powder was mixed with lukewarm water with proper and continuous stirring getting the proper homogeneous mixture. After this the control and experimental product which needed to be analyzed in the laboratory test. In this part of the study, both control as well as experimental products were undergone for Nutrient Analysis of fat and ash contents and were estimated by standard AOAC, 1984 methods. The nitrogen content was estimated by Khjeldhal (1883) method. Carbohydrate content was
Analysed by Anthrone method. (Hedge and Hofreiter, 1962). The samples were ash in a muffle furnace and then ash solution was prepared from this ash solution the Iron was estimated by colorimetrically using the Dipyridyl method of Ramsay (1954). Calcium was analyzed by precipitation as calcium oxalate and subsequent titration by potassium permanganate by the method of titrimetric method of Clark and Collip (1925). Phosphorus was estimated by colorimetric method of Fiske and Subbarow (1925). Insoluble and soluble dietary fibre was estimated by AOAC method. 
Zinc was determined by titrimetric method of Jeffery et al. (1889).

After that Physical Analysis was carried out by The Water Holding Capacity (WHC) of the samples were determined by the centrifuge technique described by percent dispersibility was determined by the method of Gandhi and Srivastava (2007).
The analysis was carried out in triplicates for all determinations. The mean, standard deviation of means, standard error of means were calculated. A multiple comparison procedure of the means was performed by the $\mathrm{T}$ test. The Correlation Coefficients were computed. Significance of the differences was defined as $\mathrm{p}<0.05$.

\section{RESULTS AND DISCCUSION}

Table 1: Nutrient Content of Control and Experimental Weaning Mix

\begin{tabular}{|c|c|c|c|c|c|}
\hline \multirow{3}{*}{ Nutrients } & \multicolumn{5}{|c|}{ Weaning Mix } \\
\hline & \multirow{2}{*}{$\begin{array}{c}\text { Cerelac } \\
(\text { Control })\end{array}$} & \multicolumn{4}{|c|}{ Experimental } \\
\hline & & $\mathbf{A}$ & $\mathbf{B}$ & $\mathbf{C}$ & $\mathbf{D}$ \\
\hline $\operatorname{Ash}(g \%)$ & $\begin{array}{c}2.763 \\
\pm 0.064\end{array}$ & $\begin{array}{c}2.725 \\
\pm 0.022 \\
\end{array}$ & $\begin{array}{c}2.655 \\
\pm 0.035\end{array}$ & $\begin{array}{c}2.470 \\
\pm 0.119\end{array}$ & $\begin{array}{c}\mathbf{2 . 7 8 0} \\
\pm 0.083 \\
\end{array}$ \\
\hline Calcium (mg\%) & $\begin{array}{l}539.259 \\
\pm 15.983\end{array}$ & $\begin{array}{l}\mathbf{6 1 5 . 1 8 5}^{* * *} \\
\pm 15.072\end{array}$ & $\begin{array}{l}550.370 \\
\pm 6.676\end{array}$ & $\begin{array}{c}185.555^{* *} \\
\pm 7.856\end{array}$ & $\begin{array}{c}402.222^{* *} \\
\pm 3.928\end{array}$ \\
\hline Phosphorus (mg\%) & $\begin{array}{c}\mathbf{2 9 6 . 3 0 5} \\
\pm 2.216\end{array}$ & $\begin{array}{c}258.947^{* *} \\
\pm 2.292\end{array}$ & $\begin{array}{c}292.820^{*} \\
\pm 4.847\end{array}$ & $\begin{array}{c}281.171^{*} \\
\pm 5.100\end{array}$ & $\begin{array}{c}288.396^{*} \\
\pm 2.967\end{array}$ \\
\hline Iron (mg\%) & $\begin{array}{l}14.590 \\
\pm 0.794\end{array}$ & $\begin{array}{l}27.360^{* *} \\
\pm 1.431\end{array}$ & $\begin{array}{l}29.970^{* *} \\
\pm 0 . .670\end{array}$ & $\begin{array}{l}28.906^{* *} \\
\pm 0.605\end{array}$ & $\begin{array}{l}\text { 33.801 }^{* *} \\
\pm 0.618\end{array}$ \\
\hline Zinc (mg \%) & $\begin{array}{c}0.553 \\
\pm 0.009\end{array}$ & $\begin{array}{l}1.315^{* *} \\
\pm 0.008\end{array}$ & $\begin{array}{l}1.466^{* \%} \\
\pm 0.009\end{array}$ & $\begin{array}{l}1.358^{* *} \\
\pm 0.008\end{array}$ & $\begin{array}{l}0.956^{* *} \\
\pm 0.003\end{array}$ \\
\hline Carbohydrate (g\%) & $\begin{array}{l}96.000 \\
\pm 0.333\end{array}$ & $\begin{array}{l}54.888^{* *} \\
\pm 0.888\end{array}$ & $\begin{array}{l}63.555^{* *} \\
\pm 0.376\end{array}$ & $\begin{array}{l}63.555^{* *} \\
\pm 0.376\end{array}$ & $\begin{array}{l}70.888^{* *} \\
\pm 0.200\end{array}$ \\
\hline Fat $(g \%)$ & $\begin{array}{c}4.666 \\
\pm 0.666\end{array}$ & $\begin{array}{c}4.666 \\
\pm 0.421\end{array}$ & $\begin{array}{c}5.333 \\
\pm 0.421\end{array}$ & $\begin{array}{c}3.666 \\
\pm 0.333\end{array}$ & $\begin{array}{l}\mathbf{7 . 3 3 3}^{*} \\
\pm 0.421\end{array}$ \\
\hline Protein $(g \%)$ & $\begin{array}{l}13.883 \\
\pm 0.583\end{array}$ & $\begin{array}{l}18.433 \\
\pm 0816\end{array}$ & $\begin{array}{l}20.008^{*} \\
\pm 0.291\end{array}$ & $\begin{array}{l}14.466 \\
\pm 0.583\end{array}$ & $\begin{array}{l}\mathbf{2 1 . 3 5 0} \\
\pm 0.534\end{array}$ \\
\hline Crude fiber (g\%) & $\begin{array}{c}0.753 \\
\pm 0.003\end{array}$ & $\begin{array}{l}1.703^{* *} \\
\pm 0.003\end{array}$ & $\begin{array}{l}1.996^{* * *} \\
\pm 0.016\end{array}$ & $\begin{array}{l}1.860^{* *} \\
\pm 0.03\end{array}$ & $\begin{array}{l}1.833^{* *} \\
\pm 0.016\end{array}$ \\
\hline $\begin{array}{l}\text { Water Holding } \\
\text { Capacity }(g \%)\end{array}$ & $\begin{array}{l}\mathbf{1 . 8 2 2} \\
\pm 0.022\end{array}$ & $\begin{array}{l}0.611^{* *} \\
\pm 0.030\end{array}$ & $\begin{array}{l}0.866^{* *} \\
\pm 0.072 \\
\end{array}$ & $\begin{array}{l}0.944^{* *} \\
\pm 0.024\end{array}$ & $\begin{array}{l}0.955^{* *} \\
\pm 0.024\end{array}$ \\
\hline
\end{tabular}

\section{Control : Cerelac Weaning Mix, A : Weaning Mix without processing}

\section{B: Malted Weaning Mix, C : Germinated Weaning Mix, D : Popped Weaning Mix}

Mean of three replication \pm SEM, Value sharing a common superscript within a control are not significant different, $* \mathrm{p}<0.05=$ significant difference, $* * p<0.01=$ highly significant difference, $\mathrm{NS}=$ Non significant difference.

Table 1 shows the nutrient contents i.e. Ash, Calcium, Phosphorus, Iron, Zinc, Carbohydrate, Fat, Protein, Crude fibre and Water holding Capacity of Control and experimental weaning mix. The calcium content was found higher in the without process weaning mix and lowest in the germinated weaning mix.
Phosphorus value of all experimental weaning mix was found lower compared to the Cerelac. The Iron and Zinc contents of all the experimental weaning mix were found higher compared to the Cerelac and it shows highly significant difference $(p<0.01)$ also. The Carbohydrate was found lower in all the 
experimental weaning mix compared to the Cerelac and they were significantly differ $(p<0.01)$ too. Protein content was also found slightly higher compared to the Cerelac and the significant difference $(p<0.05)$ was seen in the Malted and Popped weaning mix in comparison of Cerelac. The Water holding capacity of all the experimental weaning mix was lowest compared to the Cerelac as the Cerelac contained higher amount of carbohydrate.

\section{CONCLUSION}

The Calcium was higher in A sample i.e. without process weaning mix. The Phosphorous and Zinc were higher in the B sample i.e. Malted weaning mix. Whereas the Iron, Carbohydrate, Fat and Protein were higher in the D sample i.e. popped weaning mix. The Crude Fibre was found higher in the all the experimental weaning mix compared of the control sample i.e. Cerelac weaning mix.

In Conclusion of the study results suggest that the weaning foods based on wheat, chickpea and ragi are nutritionally balanced and possess good growth promoting quality. The traditional technologies such as Malting, Germinating and Popping of cereals and legumes could be easily adapted to prepared weaning and supplementary foods from wheat, chickpea and ragi. Malting, Germinating and Popping have a high potential for developing low cost weaning and supplementary foods.

\section{REFRENCES}

$>$ AOAC (1984), "Official Method of Analysis" 14th Edn. Associationn of official analytical chemists, Washington DC.

$>$ Clark F. P. and Collip J. B, (1925),'Determination of calcium by titremetric method", journal of biological chemistry, 63,461.

$>$ Ezeji C. and Ojimelukwe P.C.(1993)," Effect of fermentation on nutritional quality and functional properties of infant food formulations prepared from pambara groundnut, fruit dip pumpkin and millet seeds", Plant Foods Hum Nutr., 44 : 267276.

$>$ Fiske C. H. and Subbarow (1925), "Colorimetric Determination of phosphorus", journal of biological chemistry, $66: 375-400$.

$>$ Gandhi, A.P. and Srivastava, T. (2007), "Studies on the production of protein isolates from defatted sesame seed (Sesamum indicum) flour and their nutritional profile, Asian Food Journal, 14(3), 175-180.

Hedge, J.E. and Hefreiter, B.T. (1962), "Methods in carbohydrate chemistry", Vol. 17 (Eds.), Whistler R.L. and BeMiller, J.N., Academic Press, New York, p.420.

$>$ Hulse J.H.(1991),"Nature, composition and utilization of grain legumes", In: Uses of Tropical Legumes: Proceedings of a Consultants' Meeting., 11-27. ICRISAT Center, ICRISAT, Patancheru, A.P. 502-324, India.

$>$ Jaffery G. H., Bassett J., Mendham J.(1989),"Vogel's quantitative analysis of chemicals", Hangman Harlow., 5 284-294.

$>$ Kamchan A., Puwastien P., Sirichakwal P.P. and Kongkachuichai R.(2004),"In vitro calcium bioavilability of vegetables, legumes and seeds", J. Food Composition and Analysis., 17 : 311-32.

$>$ Kjeldahl, J. (1883), New method for the determination of nitrogen in organic substances, Zeitschrift fur analytische chemie, 22(1): 366-383.

$>$ Mahajan P.V. and Chattopadhey P.K.(2000),"Development of chemically leavened cereal legume based instant mix (dhokla)",J Food Technol., 37 : 459-464.

$>$ Negi A., Boora P. and Khetarpaul N.(2001),"Starch and protein digestibility of newly released moth bean cultivars: Effect of soaking, dehulling, germination and pressure cooking",Nahrung., 45(4) : 251-254.

$>$ Preet K., Punia D.(2000), "Antinutrients and digestibility (in vitro) of soaked, dehulled and germinated cowpeas", Nutr. Health., 14(2) : 109117.

$>$ Ramsay W. N. M.(1969),"Method of iron estimation", journal of biological chemistry,17, Practical clinical biochemistry - 4th edition.

$>$ Sattar A., Durrani S.K., Mahmood F., Ahnad A. and Khan I.(1989), "Effect of soaking and germination temperatures on selected nutrients and antinutrients of mung bean", Food Chem., 34 : 111-120.

Savelkoul F.H.M.G., Vanderpeol A.F.B. and Tamminga S.(1992),"The presence and inactivation of trypsin inhibitors, tannins, lectins and amylase inhibitors in legume seeds during germination. A review",Plant Foods for Human Nut., 42 : 71-85.

$>$ Usha R., Lakshni M. and Ranjani M.(2010), " Nutritional, Sensory and Physical Analysis of Pumpkin Flour Incorporated into Weaning Mix", Mal J Nutr., 16(3) : 379-387. 